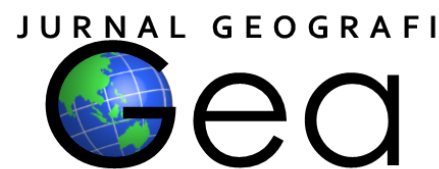

\title{
ESTIMASI KOORDINAT TITIK KONTROL PEMANTAUAN DEFORMASI BENDUNGAN SERMO DENGAN METODE PARAMETER BERTAHAP DARI DATA BASELINE HASIL PENGOLAHAN GAMIT
}

\author{
Asri Ria Affriani ${ }^{1}$, Nurrohmat Widjajanti ${ }^{2}$, Yulaikhah $^{3}$ \\ ${ }^{1}$ Departemen Pendidikan Geografi, FPIPS, UPI \\ ${ }^{23}$ Departemen Teknik Geodesi, FT, UGM \\ 1.asriria_affriani@upi.edu, ${ }^{2}$ n.widjajanti@gmail.com, ${ }^{3}$ yulaikah@gmail.com
}

\begin{abstract}
Sermo Dam is an importance building structure that serves as a water reservoir of clean water, irrigation water, as well as flood protection in Kulon Progo. Because of that, it needs to be monitored to detect any deformation. Geodinamic movement, expansion of area monitoring, and detection of ground cracks require by adding the number of control points. The addition of control points in a measurement requires specific data processing strategy. Therefore, it used the sequential adjustment method. This research aims to identify $3 D$ coordinate values and the difference precision of the control points from the sequential adjustment method also to identify the significance different of the coordinates and its precision between sequential adjustment and GAMIT/GLOBK processing.

This research uses GNSS observation data from 10 deformation monitoring control points that was measured on doy 250 in 2014 and doy 129 in 2015. The observation was done for \pm 2 hours for doy 250 in 2014 and \pm 8 hours for doy 129 in 2015. Data processing was performed by GAMIT with local reference point of six BIG's CORS stations. The first step of sequential adjustment used five control points with one point considered fixed. The second step was added with five control points.

The difference of the coordinate precision analysis using sequential adjustment method indicate that there are increased precision in five control points which are processed in the first step. The addition of the coordinate precision ranges from $0.193 \mathrm{~cm}$ to $5,450 \mathrm{~cm}$. Based on the comparative of two variants sample test shows that the precision of coordinates resulted for the first step is significant different from the second step. The results of the two significance parameter test indicate that the coordinate of the result of sequential adjustment method does not significantly different to the result of GAMIT/GLOBK software
\end{abstract}

Keywords: the addition of control point, sequential adjustment method, the addition of the coordinate precision

\footnotetext{
ABSTRAK

Bendungan Sermo merupakan suatu bangunan struktur yang berfungsi sebagai penampung air untuk air bersih, irigasi pengairan, serta pencegah banjir di Kabupaten Kulon Progo. Oleh karena pentingnya bangunan tersebut, perlu dilakukan pemantauan guna mendeteksi adanya deformasi. Adanya pergerakan geodinamik, perluasan area pemantauan, dan deteksi retakan tanah (crack) memerlukan penambahan jumlah titik kontrol pemantauan deformasi. Penambahan titik kontrol dalam suatu pengukuran dapat mempengaruhi ketelitian hasil pengolahan data sehingga memerlukan strategi khusus pengolahan data. Oleh karena itu, digunakan hitung perataan metode parameter bertahap. Tujuan dari penelitian ini adalah teridentifikasi nilai koordinat 3D dan perbedaan ketelitian titik kontrol pemantaun deformasi yang dihasilkan dari pengolahan dengan metode parameter bertahap serta teridentifikasi signifikansi perbedaan koordinat dan ketelitian hasil pengolahan metode parameter bertahap dengan hasil pengolahan dengan perangkat lunak GAMIT/GLOBK.
} 
Penelitian ini menggunakan data pengamatan GNSS 10 titik kontrol pemantauan deformasi Bendungan Sermo yang diukur pada day of year (doy) 250 tahun 2014 selama \pm 2 jam dan doy 129 tahun $2015 \pm 8$ jam. Pengolahan data dilakukan dengan perangkat lunak GAMIT untuk mendapatkan panjang baseline dan ketelitiannya dengan pengikatan lokal pada enam stasiun CORS BIG. Nilai panjang baseline dan ketelitiannya digunakan sebagai input dalam pengolahan dengan hitung perataan parameter bertahap sehingga dihasilkan nilai koordinat titik kontrol pemantauan deformasi dan ketelitannya. Pada perataan bertahap tahap pertama digunakan lima titik kontrol dengan satu titik dianggap fixed. Perataan bertahap tahap kedua ditambahkan lima titik kontrol. Analisis yang dilakukan meliputi analisis perbedaan ketelitian pada titik kontrol pemantauan hasil pengolahan data dengan metode parameter bertahap dan perbandingan koordinat 3D hasil pengolahan metode parameter bertahap dengan hasil pengolahan GAMIT/GLOBK.

Analisis perbedaan ketelitian hasil pengolahan data menggunakan metode parameter bertahap menunjukkan bahwa terdapat peningkatan ketelitian pada kelima titik kontrol yang diolah pada tahap pertama. Peningkatan ketelitian berkisar antara $0,193 \mathrm{~cm}$ s.d. $5,450 \mathrm{~cm}$. Berdasarkan uji perbandingan dua varian sampel, ketelitian hasil pengolahan tahap pertama berbeda signifikan dengan ketelitian hasil pengolahan tahap kedua. Hasil uji signifikansi beda dua parameter menunjukkan bahwa hasil pengolahan koordinat 3D dengan metode perataan bertahap tidak berbeda signifikan dengan hasil pengolahan dengan perangkat lunak GAMIT/GLOBK secara statistik.

Kata kunci: penambahan titik kontrol, perataan metode parameter bertahap, peningkatan ketelitian koordinat.

\section{PENDAHULUAN}

Bendungan Sermo merupakan suatu bangunan struktur yang berfungsi sebagai penampung air untuk air bersih, irigasi pengairan, serta pencegah banjir di Kabupaten Kulon Progo. Mengingat fungsi vital Bendungan Sermo bagi masyarakat Kabupaten Kulon Progo, maka diperlukan pengawasan dan pemeliharaan guna menghindari kerusakan pada bendungan. Salah satu bentuk dari upaya tersebut adalah dengan melakukan pemantauan deformasi. Penelitian terdahulu terdahulu menggunakan metode terestris untuk pemantauan titik kontrol deformasi. Dalam penelitian ini digunakan metode survei GNSS. Keuntungan menggunakan metode GNSS adalah titik kontrol pemantauan tidak perlu saling terlihat dan koordinat titik ditentukan dalam kerangka referensi tertentu (Hudnut dan Behr, 1998).

Berdasarkan penelitian Waljiyanto, dkk, (2015) terdapat sesar aktif Parangtritis-Kulon Progo yang melewati Bendungan Sermo. Keberadaan sesar tersebut dimungkinkan mengakibatkan pergerakan geodinamik yang berakibat pada ketahanan struktur bangunan bendungan. Oleh karena itu, pada penelitian ini ditambahkan titik kontrol pengukuran guna mendeteksi pergerakan yang terjadi akibat adanya sesar tersebut. Selain adanya pergerakan geodinamik, adanya perluasan area pemantauan dan deteksi retakan tanah (crack) juga dapat mengakibatkan penambahan jumlah titik kontrol pemantauan.

Adanya penambahan titik kontrol dalam suatu pengukuran memerlukan strategi pengolahan data khusus untuk mengetahui besarnya perbedaan ketelitian yang dihasilkan. Oleh karena itu, digunakan pengolahan hitung perataan metode bertahap (Mikhail dan Ackermann, 1976). Selain itu, uji statistik dilakukan pada koordinat hasil pengolahan metode hitung perataan bertahap dan hasil pengolahan dengan perangkat lunak GAMIT/GLOBK. Hal ini dilakukan untuk membandingkan hasil pengolahan perataan bertahap dengan hasil pengolahan perangkat lunak ilmiah yang sudah ada.

\section{METODE PENELITIAN}

Pelaksanaan penelitian ini dibagi dalam beberapa tahapan, yaitu persiapan, pengumpulan data, kontrol kualitas dengan TEQC, pengolahan data dengan metode parameter bertahap dan pengolahan data dengan GAMIT/GLOBK. Pelaksanaan penelitian secara skematik tersaji dalam diagram alir Gambar 1. 


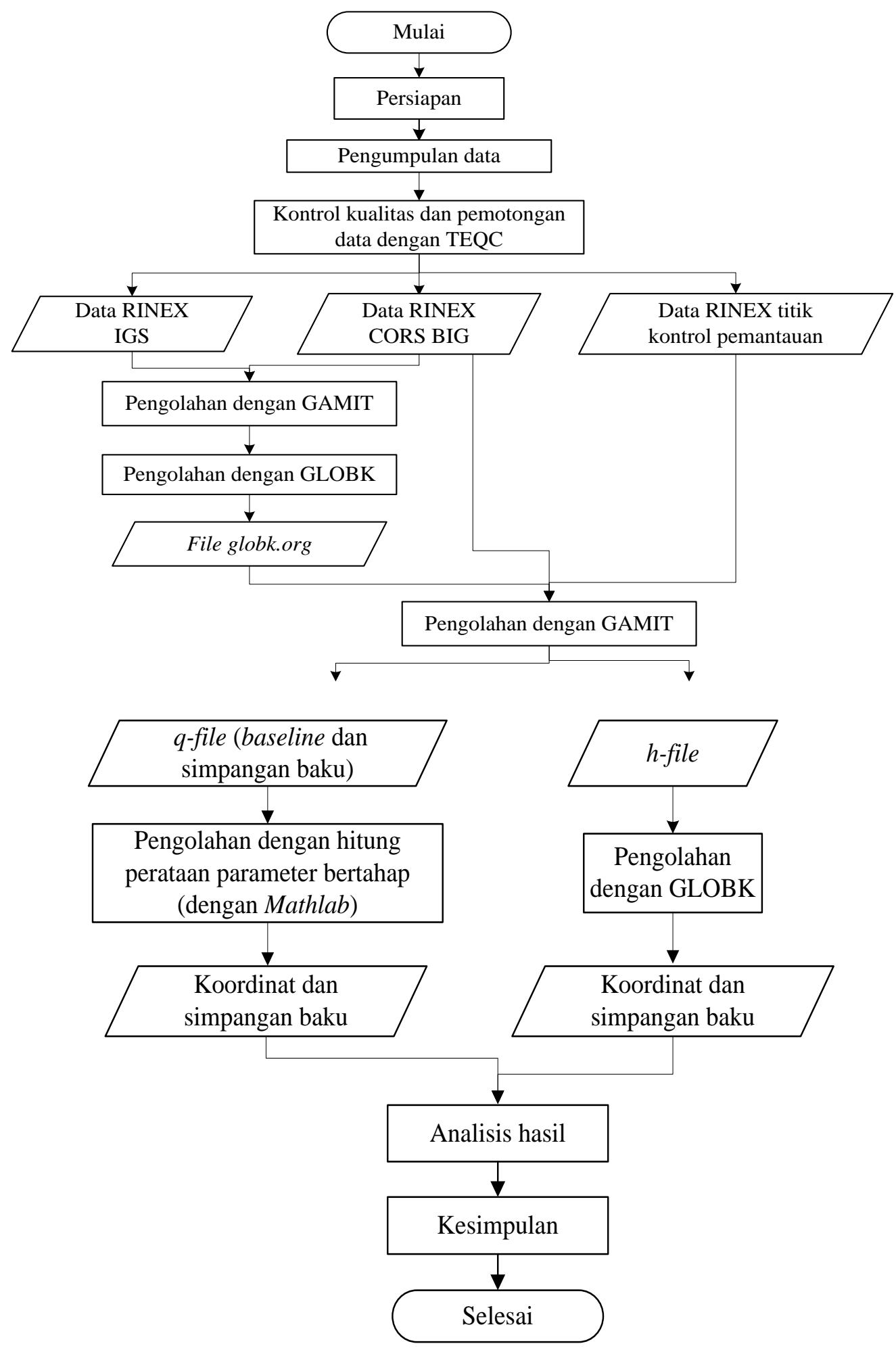

Gambar 1. Diagram alir penelitian secara skematik

Gambar 1 menunjukkan tahapan-tahapan dalam penelitian ini. Tahap persiapan meliputi pengumpulan data penelitian. Data penelitian ini tersaji dalam Tabel 1.

Tabel 1. Data penelitian

\begin{tabular}{|c|c|}
\hline doy & Data \\
\hline \multirow{2}{*}{250} & 1. Data pengamatan delapan titik kontrol pemantauan (BMS1, BMS2, \\
tahun & BMS3, BMS5, BMB1, BMB2, dan BMB5) \\
\cline { 2 - 2 } 2014 & 2. Data pengamatan enam stasiun CORS BIG (CBTL, CMGL, CPBL, \\
& CPWD, CSEM dan CSLO) \\
\hline
\end{tabular}




\begin{tabular}{|c|c|}
\hline & 3. Data pengamatan 10 stasiun IGS \\
\hline \multirow{2}{*}{129} & 1. Data pengamatan enam titik kontrol pemantauan (BMS1, MAK1, \\
tahun & MAK2, MAK3, MAK4 dan MAK5) \\
\cline { 2 - 2 } 2015 & $\begin{array}{c}\text { 2. Data pengamatan enam stasiun CORS BIG (CBTL, CMGL, CPBL, } \\
\text { CPWD, CSEM dan CSLO) }\end{array}$ \\
\hline
\end{tabular}

Pemotongan data per dua jam pada data enam titik kontrol pemantauan doy 129 tahun 2015 dan kontrol kualitas dengan TEQC.
Pembuatan project pengolahan untuk mempermudah pengorganisasian data. Project penelitian tersaji pada Tabel 2 .

Tabel 2.a Penggunaan data masing-masing project pengolahan

\begin{tabular}{|c|c|c|c|c|}
\hline Pengolahan & Project & Stasiun pengamatan & Titik ikat & doy \\
\hline $\begin{array}{l}\text { Pengolahan } \\
\text { dengan titik } \\
\text { ikat global }\end{array}$ & ske5 & $\begin{array}{l}\text { CBTL, CMGL, } \\
\text { CPBL, CPWD, } \\
\text { CSEM, CSLO }\end{array}$ & $\begin{array}{lr}\text { CNMR, } & \text { COCO, } \\
\text { DARW, } & \text { DGAR, } \\
\text { KARR, PARK, PBR2, } \\
\text { PIMO, TOW2, XMIS }\end{array}$ & $\begin{array}{l}250 \text { tahun } \\
2014\end{array}$ \\
\hline
\end{tabular}

Lanjutan Tabel 2.b. Penggunaan data masing-masing project pengolahan

\begin{tabular}{|c|c|c|c|c|}
\hline Pengolahan & Project & Stasiun pengamatan & Titik ikat & doy \\
\hline \multirow{2}{*}{$\begin{array}{l}\text { Pengolahan } \\
\text { dengan titik } \\
\text { ikat global }\end{array}$} & ske6 & $\begin{array}{l}\text { CBTL, CMGL, } \\
\text { CPBL, CPWD, } \\
\text { CSEM, CSLO }\end{array}$ & $\begin{array}{lr}\text { CNMR, } & \text { COCO, } \\
\text { DARW, } & \text { DGAR, } \\
\text { KARR, PARK, PBR2, } \\
\text { PIMO, TOW2, XMIS }\end{array}$ & $\begin{array}{l}129 \text { tahun } \\
2015\end{array}$ \\
\hline & $\operatorname{cam} 2$ & $\begin{array}{l}\text { CBTL, CMGL, } \\
\text { CPBL, CPWD, } \\
\text { CSEM, CSLO }\end{array}$ & $\begin{array}{l}\text { CNMR, } \\
\text { DARW, } \\
\text { KARR, PARK, PBR2, } \\
\text { PIMO, TOW2, XMIS }\end{array}$ & $\begin{array}{l}250 \text { tahun } \\
2014 \text { dan } \\
129 \text { tahun } \\
2015\end{array}$ \\
\hline \multirow{3}{*}{$\begin{array}{l}\text { Pengolahan } \\
\text { dengan titik } \\
\text { ikat lokal }\end{array}$} & ske7 & $\begin{array}{lr}\text { BMS1, BMS2,BMS3, } \\
\text { BMS5, } \\
\text { BMB1, } \\
\text { BMB5 }\end{array}$ & $\begin{array}{l}\text { CBTL, CMGL, } \\
\text { CPBL, CPWD, } \\
\text { CSEM, CSLO }\end{array}$ & $\begin{array}{l}250 \text { tahun } \\
2014\end{array}$ \\
\hline & ske8 & $\begin{array}{l}\text { BMS1, } \quad \text { MAK1, } \\
\text { MAK2, } \\
\text { MAK4, MAK5 }\end{array}$ & $\begin{array}{ll}\text { CBTL, } & \text { CMGL, } \\
\text { CPBL, } & \text { CPWD, } \\
\text { CSEM, CSLO } & \end{array}$ & $\begin{array}{l}129 \text { tahun } \\
2015\end{array}$ \\
\hline & $\operatorname{cam} 3$ & $\begin{array}{l}\text { BMS1, BMS2,BMS3, } \\
\text { BMS5, } \\
\text { BMB1, } \\
\text { BMB56, } \\
\text { BMB2, } \\
\text { MAK4, MAK5 }\end{array}$ & $\begin{array}{l}\text { CBTL, CMGL, } \\
\text { CPBL, CPWD, } \\
\text { CSEM, CSLO }\end{array}$ & $\begin{array}{l}250 \text { tahun } \\
2014 \text { dan } \\
129 \text { tahun } \\
2015\end{array}$ \\
\hline
\end{tabular}

Pengolahan data titik kontrol pemantauan menggunakan pengikatan lokal pada enam stasiun CORS BIG. Pengolahannya adalah enam stasiun CORS BIG diolah dengan GAMIT/GLOBK dan diikatkan pada 10 stasiun IGS. Hasil pengolahan berupa file globk.org yang dijadikan file apriori digunakan untuk acuan pengikatan lokal. Pengolahan dengan GAMIT untuk mendapatkan panjang baseline beserta simpangan bakunya dalam sistem koordinat kartesi 3D. Pada pengolahan data delapan titik kontrol pemantauan doy 129 tahun 2015, terdapat tiga titik kontrol yang datanya tidak dapat diolah. Hal ini karena lama pengamatan pada ketiga titik tersebut kurang dari dua jam. Ketiga titik tersebut adalah BMS3, BMS6, dan BMS5. Pengolahan selanjutnya digunakan lima titik kontrol pemantauan.

Pengolahan dengan parameter bertahap dipisahkan menjadi tahap pertama dan kedua. Pengolahan tahap pertama menggunakan data pengamatan doy 250 tahun 2014, sedangkan 
tahap kedua menggunakan doy 250 tahun 2014 dan data doy 129 tahun 2015. Pembentukan komponen matriks pada perataan bertahap $\mathrm{A}, \mathrm{P}, \mathrm{L}$, dan $\mathrm{X}$ sesuai dengan persamaan 2.1 dan 2.2 yang didasarkan pada data hasil pengolahan GAMIT.

$$
\begin{aligned}
& V_{1}=A_{1} X+L_{1} \\
& V_{2}=A_{2} X+L_{2}
\end{aligned}
$$

Dalam hal ini, $V_{1}, V_{2}$ adalah matriks residu untuk kelompok data pertama dan kedua, $A_{1}, A_{2}$ adalah matriks desain untuk kelompok data pertama dan kedua, $X$ adalah matriks parameter, dan $L$ adalah matriks sisa. Nilai parameter dihitung dengan persamaan 2.3.

$$
\begin{aligned}
& X_{2}=X_{1}+\Delta X \\
& X_{1}=-\left(A_{1}^{T} P_{1} A_{1}\right)^{-1} A_{1}^{T} P_{1} L_{1} \\
& \Delta X=-\left(A_{1}^{T} P_{1} A_{1}\right)^{-1} A_{2}^{T} T\left(A_{2} X_{1}+L_{2}\right) \\
& T=\left(P_{2}^{-1}+A_{2}\left(A_{1}^{T} P_{1} A_{1}\right)^{-1} A_{2}^{T}\right)^{-1}
\end{aligned}
$$

Dalam hal ini, $X_{2}$ adalah parameter (koordinat) hasil perataan tahap kedua, $\Delta X$ adalah kontribusi pengukuran baru terhadap parameter perataan tahap pertama, dan adalah parameter (koordinat) hasil perataan tahap pertama.

Matriks $\mathrm{P}$ perataan bertahap pada tahap pertama $\left(P_{1}\right)$ digunakan nilai varian kovarian dari baseline hasil pengolahan GAMIT. Matriks $P$ perataan bertahap pada tahap kedua $\left(P_{1}\right)$ dihitung dengan menggunakan hukum perambatan kesalahan dengan input dari matriks varian kovarian perataan bertahap pada tahap pertama. Nilai ketelitian parameter dapat dihitung dari matriks kofaktor parameter. Matriks kofaktor parameter tahap kedua $\left(\mathrm{Q}_{\mathrm{x} 2}\right)$ dapat dicari dengan menggunakan persamaan 2.7.

$$
\begin{aligned}
& Q_{x_{2}}=Q_{x_{1}}+\Delta Q \\
& Q_{x_{1}}=\left(A_{1}^{T} P_{1} A_{1}\right)^{-1} \\
& \Delta Q=\left(A_{1}^{T} P_{1} A_{1}\right)^{-1} A_{2}^{T} T A_{2}\left(A_{1}^{T} P_{1} A_{1}\right)^{-1}
\end{aligned}
$$

Dalam hal ini, $\mathrm{Q}_{\mathrm{x} 2}$ adalah matriks kofaktor parameter tahap kedua, $\Delta Q_{x}$ adalah kontribusi pengukuran baru terhadap kofaktor parameter, dan $\mathrm{Q}_{\mathrm{x} 1}$ adalah matriks kofaktor parameter tahap pertama. Nilai ketelitian dari tiap-tiap parameter yang bersesuaian didapat dari akar elemen diagonal matriks $\mathrm{Q}_{\mathrm{x} 2}$ dikalikan aposteori varian.

Analisis hasil perhitungan menggunakan uji perbandingan dua varian sampel. Uji ini membandingkan varian koordinat titik kontrol pemantauan pada tahap pertama dengan tahap kedua. Analisis juga dilakukan dengan uji sig(2̂fill)ansi beda dua parameter antara hasil (peßàtaan bertahap dengan hasil perhitungan dengan GLOBK.

\section{HASIL DAN PEMBAHASAN}

Hasil penelitian ini meliputi hasil pemilihan data dan kontrol kualitas data dengan TEQC, hasil pengolahan data dengan GAMIT/GLOBK pada stasiun CORS BIG, hasil pengolahan data dengan GAMIT pada data titik kontrol pemantauan, hasil pengolahan GLOBK pada data titik kontrol pemantauan, dan hasil perhitungan koordinat dengan perataan parameter bertahap.

\section{Hasil pemilihan data dan kontrol kualitas dengan TEQC}

Pemilihan data stasiun GNSS dilakukan dengan pemotongan per dua jam pada data pengamatan doy 129 tahun 2015 yaitu pada titik BMS1, MAK1, MAK2, MAK3, MAK4, dan MAK5. Rentang waktu pukul 6.00 s.d. 8.00 merupakan data dengan kualitas terbaik hasil dari pemotongan data per dua jam.

Kontrol kualitas dengan TEQC didasarkan pada tiga parameter kontrol kualitas yaitu persentase perekaman penuh, efek multipath pada sinyal L1 dan L2, dan pengaruh kondisi atmosfer pada lapisan ionosphere. Pada titik CSEM doy 250 tahun 2014, ketiga parameter tidak memenuhi kriteria, tetapi lama pengamatan pada titik CSEM cukup panjang yaitu 24 jam. Hal ini dapat mereduksi efek multipath, sehingga data tersebut masih dapat digunakan untuk pengolahan GAMIT. Pada stasiun BMS5 doy 250 tahun 2014 ketiga parameter juga tidak terpenuhi. Hal ini karena lama pengamatan pada doy 250 tahun 2014 yaitu \pm 2 jam dan lokasi titik di area kaki bendungan, sehingga ruang pandang satelit sedikit. Namun, data pada titik BMS5 tetap digunakan dalam pengolahan GAMIT walaupun hasil kontrol kualitas tidak memenuhi kriteria karena ketersediaan data yang terbatas, sehingga 
tidak dapat dilakukan pemilihan data seperti pada doy 129 tahun 2015.

\section{Hasil pengolahan GAMIT/GLOBK pada stasiun CORS BIG}

Hasil pengolahan GAMIT berupa h-file digunakan untuk pengolahan dengan GLOBK. Berdasarkan evaluasi yang telah dilakukan, semua stasiun CORS BIG pada semua project pengolahan memenuhi kriteria pengolahan GAMIT yaitu nilai fract $<10$ dan nilai postfit nrms $<0,25$. Hal ini menunjukkan tidak ada efek cycle slip yang belum dihilangkan berkaitan dengan parameter bias ekstra atau terdapat kesalahan dalam pemodelan (Anonim, 2000).

Hasil pengolahan GLOBK adalah koordinat 3D dan ketelitian koordinat enam stasiun CORS BIG dalam sistem koordinat kartesi 3D. Koordinat dan ketelitian yang dihasilkan dari pengolahan GLOBK terdapat pada project cam2. Evaluasi hasil pengolahan dengan GLOBK menunjukan bahwa nilai $\mathrm{x} 2 / \mathrm{f}<10$ sehingga memenuhi kriteria. Berdasarkan hasil pengolahan, menunjukkan bahwa enam stasiun CORS BIG pada project cam2, memiliki simpangan baku antara 0,181 $\mathrm{cm}$ s.d. $0,753 \mathrm{~cm}$ pada komponen $\mathrm{X}, \mathrm{Y}$, maupun Z. Hasil tersebut sudah cukup baik untuk dijadikan sebagai titik ikat lokal untuk pengolahan data titik kontrol pemantauan. Hasil pengolahan GLOBK berupa file globk.org kemudian dikonversi untuk dijadikan file apriori untuk pengolahan selanjutnya.

\section{Hasil pengolahan GAMIT pada data titik kontrol pemantauan}

Hasil pengolahan GAMIT adalah q-file dan h-file masing-masing doy pengamatan. Project yang diolah adalah project ske7 dan ske8. q-file digunakan sebagai input untuk pengolahan dengan perataan parameter bertahap, sedangkan h-file digunakan sebagai input pada pengolahan dengan GLOBK. Hasil pengolahan GAMIT berupa q-file berisi panjang baseline 3D dan simpangan baku. Pada project ske7 terbentuk 10 baseline antar titik pemantauan, sedangkan pada project ske8 terbentuk 15 baseline. Simpangan baku project ske7 dan ske8 yang terbesar cenderung terjadi pada komponen $\mathrm{Y}$ diikuti komponen X. Hal ini disebabkan oleh lokasi Indonesia yang terletak di sekitar kawasan ekuator dan berada di belahan bujur timur, sehingga sumbu $\mathrm{Y}$ menunjukkan arah vertikal. Komponen vertikal memiliki ketelitian lebih rendah karena faktor geometri satelit yang tidak memungkinkan untuk mengamati satelit yang terletak dibawah horison, sehingga kekuatan jaring untuk komponen vertikal menjadi lebih lemah jika dibandingkan dengan kekuatan jaring horizontal.

Simpangan baku project ske7 dan ske 8 berkisar antara 0,601 cm s.d. 20,213 cm. Pada project ske7 pola simpangan baku cenderung variatif. Simpangan baku baseline dari atau ke BMS5 mempunyai simpangan baku terbesar dibanding dengan titik-titik lain pada keempat komponen baseline. Hal ini dipengaruhi oleh kualitas data pada titik BMS5 yang buruk. Pada project ske8 pola simpangan baku baseline antar titik kontrol pemantauan relatif sama pada masing-masing komponen. Hal ini karena sebelum pengolahan dilakukan pemilihan dahulu pada potongan data per dua jam pada titik kontrol pemantauan deformasi, sehingga data yang digunakan kualitasnya cukup baik.

Hasil pengolahan GLOBK pada data titik kontrol pemantauan

Hasil pengolahan GLOBK adalah koordinat 3D dan simpangan baku koordinat 10 titik kontrol pemantauan dalam sistem koordinat kartesi 3D. Koordinat dan simpangan baku yang dihasilkan dari pengolahan GLOBK terdapat pada project cam3. Simpangan baku yang dihasilkan pada pengolahan GLOBK berkisar $1,070 \mathrm{~cm}$ s.d. $15,728 \mathrm{~cm}$. Simpangan baku komponen Y cenderung memiliki tingkat ketelitian lebih rendah dari pada simpangan baku komponen $\mathrm{X}$, dan Z. Hal ini disebabkan oleh lokasi Indonesia yang terletak di sekitar kawasan ekuator dan berada di belahan bujur timur, sehingga sumbu $\mathrm{Y}$ menunjukkan arah vertikal.

\section{Hasil pengolahan dengan perataan parameter bertahap}

Input data perataan parameter bertahap adalah q-file data doy 250 tahun 2014. Hasil dari hitung perataan ini adalah nilai estimasi matriks $\mathrm{X}$ tahap pertama dan kedua, nilai matriks kofaktor parameter (Qx). Nilai koordinat titik yang dihasilkan dalam perataan 
tahap pertama yaitu, BMS1, BMS2, BMS5, dan BMB2 beserta simpangan bakunya. Perhitungan dilakukan dengan menjadikan titik BMB1 menjadi fixed. Koordinatnya adalah -2174072,399 m; 5933543,933 m; $862689,652 \mathrm{~m}$. Hasil dari perataan tahap pertama tersaji dalam Tabel 3.

Tabel 3. Koordinat dan simpangan baku hasil perataan tahap pertama

\begin{tabular}{|c|c|c|c|c|c|c|c|}
\hline No. & $\begin{array}{c}\text { Nama } \\
\text { titik }\end{array}$ & $\mathbf{X}(\mathbf{m})$ & $\mathbf{Y}(\mathbf{m})$ & $\mathbf{Z}(\mathbf{m})$ & $\begin{array}{c}\boldsymbol{\sigma X} \\
(\mathbf{c m})\end{array}$ & $\begin{array}{c}\boldsymbol{\sigma Y} \\
(\mathbf{c m})\end{array}$ & $\begin{array}{c}\boldsymbol{\sigma Z} \\
(\mathbf{c m})\end{array}$ \\
\hline 1 & BMS1 & $-2173994,722$ & 5933592,585 & $-862625,393$ & 1,265 & 2,843 & 0,615 \\
\hline 2 & BMS2 & $-2174236,963$ & 5933501,312 & $-862561,590$ & 0,983 & 2,055 & 0,502 \\
\hline 3 & BMS5 & $-2174219,433$ & 5933435,029 & $-862704,217$ & 7,921 & 10,086 & 2,369 \\
\hline 4 & BMB2 & $-2174225,656$ & 5933530,935 & $-862459,540$ & 1,012 & 2,102 & 0,527 \\
\hline
\end{tabular}

Berdasarkan Tabel 3, simpangan baku terbesar pada komponen $\mathrm{X}, \mathrm{Y}$ dan $\mathrm{Z}$ terdapat pada titik BMS5 berturut-turut sebesar 7,921 $\mathrm{cm}, 10,086$ dan $2,369 \mathrm{~cm}$. Hal ini sesuai dengan hasil kontrol kualitas data dengan TEQC yang menyatakan bahwa titik BMS5 mempunyai kualitas yang buruk. Hal tersebut menjadikan simpangan baku titik BMS5 terbesar dibandingankan dengan titik lainnya. Pada perataan tahap kedua ini ditambahkan lima titik kontrol pemantauan deformasi yang diukur pada doy 129 tahun 2015. Kelima titik tersebut adalah MAK1, MAK2, MAK3, MAK4 dan MAK5. Namun demikian, simpangan baku hasil dari perataan ini adalah simpangan baku dari titik kontrol pemantauan yang digunakan pada tahap pertama. Hal ini karena dalam perataan bertahap hanya dihasilkan nilai pengaruh peningkatan ketelitian akibat penambahan titik pada tahap kedua. Hasil dari perataan tahap kedua tersaji dalam Tabel 4.

Tabel 4. Koordinat dan simpangan baku hasil perataan tahap kedua

\begin{tabular}{|l|l|l|l|l|l|l|l|}
\hline No. & $\begin{array}{l}\text { Nama } \\
\text { titik }\end{array}$ & $\mathbf{X}(\mathbf{m})$ & $\mathbf{Y}(\mathbf{m})$ & $\mathbf{Z}(\mathbf{m})$ & $\begin{array}{l}\boldsymbol{\sigma X} \\
(\mathbf{c m})\end{array}$ & $\begin{array}{l}\boldsymbol{\sigma Y} \\
(\mathbf{c m})\end{array}$ & $\begin{array}{l}\boldsymbol{\sigma Z} \\
(\mathbf{c m})\end{array}$ \\
\hline 1 & BMS1 & $-2173994,722$ & 5933592,585 & $-862625,393$ & 0,678 & 1,525 & 0,345 \\
\hline 2 & BMS2 & $-2174236,963$ & 5933501,312 & $-862561,590$ & 0,603 & 1,264 & 0,309 \\
\hline 3 & BMS5 & $-2174219,433$ & 5933435,029 & $-862704,217$ & 3,578 & 4,636 & 1,089 \\
\hline 4 & BMB2 & $-2174225,656$ & 5933530,935 & $-862459,540$ & 0,617 & 1,287 & 0,321 \\
\hline 5 & MAK1 & $-2173894,903$ & 5933154,652 & $-865359,084$ & N/A & N/A & N/A \\
\hline 6 & MAK2 & $-2177261,437$ & 5932017,417 & $-864474,108$ & N/A & N/A & N/A \\
\hline 7 & MAK3 & $-2177051,141$ & 5932473,456 & $-861869,906$ & N/A & N/A & N/A \\
\hline 8 & MAK4 & $-2172643,042$ & 5934345,963 & $-860932,180$ & N/A & N/A & N/A \\
\hline 9 & MAK5 & $-2171606,463$ & 5934545,293 & $-862382,573$ & N/A & N/A & N/A \\
\hline
\end{tabular}

Berdasarkan Tabel 3 dan 4, terdapat perbedaan simpangan baku yang dihasilkan dari perataan bertahap pada tahap pertama dan kedua. Nilai perbedaan ketelitian diakibatkan oleh penambahan jumlah titik yang diikutkan dalam perataan. Dalam penelitian ini, adanya lima titik tambahan
(MAK1, MAK2, MAK3, MAK4 dan MAK5) pada perataan tahap kedua mengakibatkan persamaan yang dibentuk untuk mendapatkan nilai koordinat titik menjadi bertambah. Visualisasi perbedaan ketelitian tersaji dalam Gambar 1. 


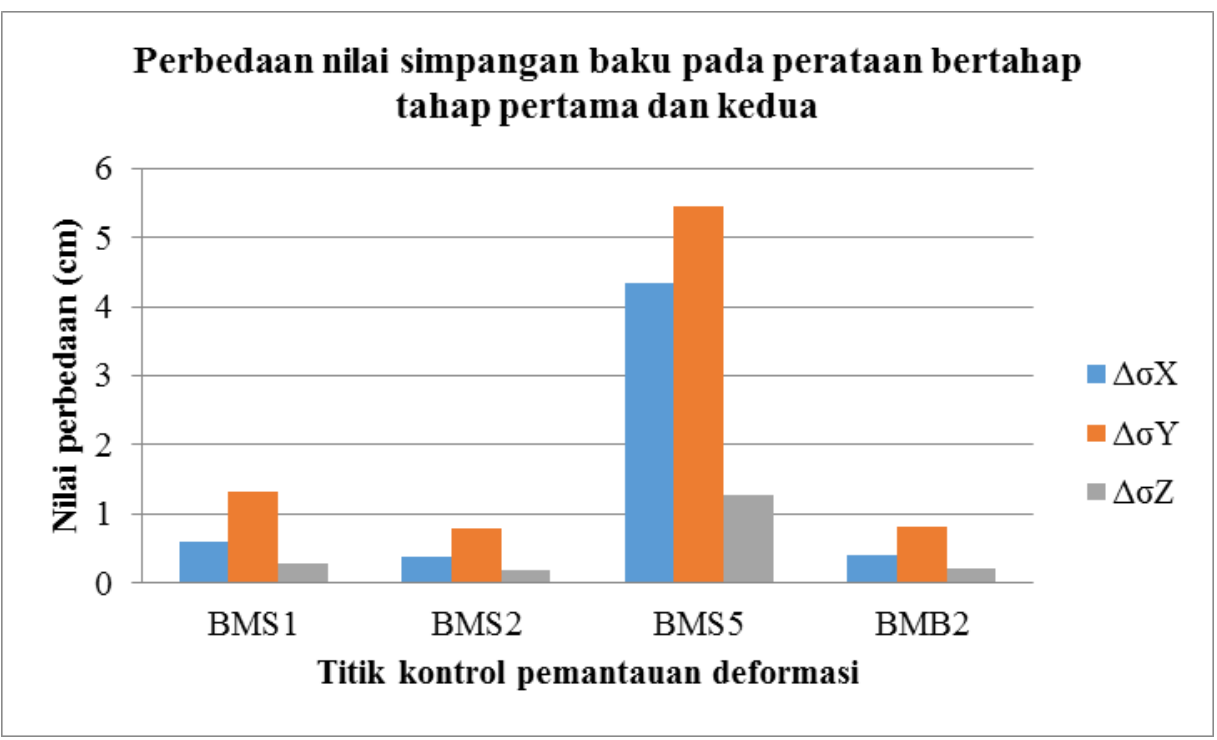

Gambar 1. Perbedaan nilai simpangan baku hasil perataan bertahap

Berdasarkan Gambar 1, simpangan baku tahap kedua cenderung lebih kecil daripada simpangan baku tahap pertama. Hal ini menandakan adanya peningkatan ketelitian pada titik BMS1, BMS2, BMS5, dan BMB2. Peningkatan ketelitian terbesar pada komponen $\mathrm{X}, \mathrm{Y}$ dan $\mathrm{Z}$ terdapat pada titik BMS5 berturut-turut sebesar 4,343 cm, 5,450 $\mathrm{cm}$ dan $1,280 \mathrm{~cm}$. Hal ini karena adanya penambahan jumlah titik kontrol pemantauan, sehingga menyebabkan jumlah persamaan yang dibentuk saat perataan menjadi bertambah. Hal ini menyebabkan nilai kesalahan suatu titik terdistribusi ke titik lainnya. Oleh sebab itu, terjadi peningkatan ketelitian pada keempat titik kontrol pemantauan deformasi tersebut.

Signifikansi peningkatan ketelitian secara statistik dapat diketahui melalui uji perbandingan dua varian sampel. Hasil uji tersebut menyatakan bahwa varian hasil perataan bertahap pada tahap pertama berbeda dengan varian pada tahap kedua secara signifikan untuk semua komponen keempat titik kontrol pemantauan. Evaluasi perbandingan hasil perataan bertahap dilakukan dengan hasil pengolahan dengan GLOBK menggunakan uji signifikansi beda dua parameter. Hasilnya adalah empat komponen koordinat berbeda secara signifikan, yaitu BMS1 pada komponen $\mathrm{X}$, BMS1 pada komponen Z, BMS2 pada komponen $\mathrm{X}$ dan BMB2 pada komponen $\mathrm{X}$. Hal ini berarti beda koordinat hasil perataan bertahap dengan hasil pengolahan dengan GLOBK tidak berbeda secara signifikan.

\section{SIMPULAN}

Simpangan baku koordinat titik kontrol pemantauan deformasi Bendungan Sermo hasil hitung perataan bertahap pada tahap pertama sebesar $0,502 \mathrm{~cm}$ s.d. $10,086 \mathrm{~cm}$ dan pada tahap kedua sebesar 0,309 cm s.d. 4,636 $\mathrm{cm}$. Penambahan jumlah titik kontrol pemantauan deformasi mengakibatkan peningkatan ketelitian sebesar $0,193 \mathrm{~cm}$ s.d. $5,450 \mathrm{~cm}$.

Peningkatan ketelitian yang terjadi berbeda signifikan secara statistik, sedangkan koordinat dan simpangan baku hasil pegolahan dengan metode perataan parameter bertahap tidak berbeda signifikan secara statistik dengan hasil pengolahan dengan perangkat lunak GAMIT/GLOBK.

\section{REKOMENDASI}

Penentuan lokasi titik kontrol pemantaun deformasi Bendungan Sermo yang baru diharapkan mempertimbangkan besarnya obstruksi area sekitar titik. Hal ini dimaksudkan agar kualitas data GNSS yang didapat cukup baik sehingga ketelitian hasil ukuran menjadi teliti. Perhitungan bobot ukuran pada perataan bertahap pada tahap kedua menggunakan hukum perambatan kesalahan acak sangat disarankan. Hal ini karena nilai koreksi kesalahan terdistribusi secara merata berdasarkan besar kesalahan yang dihasilkan setiap parameter ukuran 


\section{DAFTAR PUSTAKA}

Anonim.(2000)."Documentation for the GAMIT GPS Analysis Software", Department of Earth, Atmospheric, and Planetary Science, Masschusetts Institute of Technology.

Blewitt, G. (1997). Basics of the GPS Technique: Observation Equations. Department of Geomatics, University of Newcastle Newcastle upon Tyne, NE1 7RU, United Kingdom.

Herring, T.A, King, R.W., dan McClussky, S.C. (2006). "Introduction to GAMIT/GLOBK", Department of Earth, Atmospheric, and Planetary Science, Massachusetts Institute of Technology.

Hoppe, M. W., Baumgart, C., Polglaze, T., \& Freiwald, J. (2018). Validity and reliability of GPS and LPS for measuring distances covered and sprint mechanical properties in team sports. PloS one, 13(2), e0192708. doi:10.1371/journal.pone.0192708

Hudnut, K.W. dan Behr, J.A. (1998). "Continous GPS Monitoring of Structural Deformation at Pacoima Dam, California", Seismological Research Letter, Vol. 09, U.S. Geological and the Southern California Earthquake Center, South Wilson Ave. Pasadena.

Klous, G., Smit, L., Borlée, F., Coutinho, R. A., Kretzschmar, M., Heederik, D., \& Huss, A. (2017). Mobility assessment of a rural population in the Netherlands using GPS measurements. International journal of health geographics, $\quad 16(1), \quad 30$. doi:10.1186/s12942-017-0103-y
Leick. A., 2004, GPS Satellite Surveying, John Wiley \& Sons, Inc, New York.

Mikhail, E.W. dan Ackermann, F. (1976), Observations and Least Squares, DunDonnelley Publisher, New York.

Waljiyanto, Widjajanti, N., Yulaikah, dan Taftazani, M.I. (2015), Pengembangan Jaring Kontrol Geodesi Pemantau Waduk Sermo", Jurnal Ilmiah Geometika, Vol. 21, Badan Informasi Geospasial, Bogor.

Whitting, M.C. dan Pope, A.J. (1976), "Adjustment of Geodetic Field Data Using A Sequential Method", NOAA Techical Memorandum NOS NGS-3, Departement of Commerce, United States.

Yulaikhah, Y., Widjajanti, N., Nugroho, P., Cahyono, B. K., Waljiyanto, W., Adi, A. D., \& Taftazani, M. I. (2016). The Analysis of Monitoring Control Point Displacement of Sermo Dam Based on the 2015-2016 GNSS Data.

Zhang, B., Yao, Y., Fok, H. S., Hu, Y., \& Chen, Q. (2016). Potential Seasonal Terrestrial Water Storage Monitoring from GPS Vertical Displacements: A Case Study in the Lower Three-Rivers Headwater Region, China. Sensors (Basel, Switzerland), 16(9), 1526. doi:10.3390/s16091526 